member. The Central Engineering Establishment, on the other hand, was the responsibility of the board member for production. It was set up in 1953 for the development and testing of new machinery. In 1962, a change in departmental responsibilities was made which brought both establishments under the directorgeneral of production, with the intention of co-ordinating all research and development in the mining field. The present director-general is $\mathrm{Mr} \mathrm{N}$. Siddall.

According to the new plan, staff at Isleworth will be moved to the establishment at Bretby, which will in future be known as the National Coal Board Mining Research and Development Establishment. There are some 685 staff members at Bretby and 310 at Isleworth. Starting in about six months time, members of the two hundred scientific staff at Isleworth will be asked to transfer, although it is, of course, realized that some may in fact be unwilling to leave the area. Clerical and industrial staff will not be asked to move, but the board says that efforts will be made to find alternative employment for them. The move is expected to be completed by the end of 1970.

The first step towards unification in 1969 will be the introduction of a single planned programme for research and development instead of one for each subject. Work being undertaken in each establishment will be combined in a number of main divisions incorporating mining techniques, mechanical engineering, coal preparation, design and construction, electrical engineering, testing, physics and administration.

\section{Move for Insect Physiology}

The Agricultural Research Council has agreed to finance a new group to study insect physiology at the Imperial College research station at Silwood, near Ascot. The group has been set up as a direct consequence of the dissolution of the ARC Unit of Insect Physiology at Cambridge, on the retirement of Professor Sir Vincent Wigglesworth, its director.

The new unit has been set up within the department of zoology and applied entomology of Imperial College, which is headed by Professor T. R. E. Southwood. It is to be led by two former members of the Cambridge unit, Dr J. S. Kennedy and Dr A. D. Lees. Dr Kennedy, who has been appointed professor of animal behaviour by the University of London, is now at Silwood Park working on the organization of the new unit, and Dr Lees will be joining him very soon. They will have a supporting staff of five and newly equipped laboratories for research on insect photoperiodism and behaviour.

Professor Kennedy and Dr Lees, who have been appointed honorary lecturers at Imperial College, have had extensive experience in insect physiology and behaviour. Before Professor Kennedy joined the ARC unit in Cambridge in 1946, he had worked on locust behaviour in the Anglo-Egyptian Sudan and the Middle East, and on mosquito behaviour at the London School of Hygiene and Tropical Medicine and at the Wellcome Entomological Field Laboratories in Esher. He also spent a year at the Malaria Research Laboratory, Tirana, Albania. His work contributed much to the understanding of insect migration, host selection and behaviour. Dr Lees joined the ARC unit shortly after its inception and moved with it to Cambridge in
1945. His work on arthropod physiology has included in particular study of the cuticle and water relations of ticks and mites, diapause and polymorphism and photoperiodism in aphids.

\section{Field Studies}

MANY former students must have pleasant memories of field courses at one or more of the centres of the Field Studies Council. Dr J. D. Carthy, the scientific director of the council, points out, however, in the council's annual report just published, that the teaching at the centres is not restricted to sixth-form classes, students and teachers. It was mainly for the amateur naturalist that the council was originally founded, and the council hopes for increasing interest from this group of persons. The interest of the general public was shown by the enthusiastic reception for the lectures to holiday-makers in the Pembrokeshire Coast National Park during the past two summers.

Much was done in the past year to establish the two new ficld centres in North Wales and Somerset. The first students arrived at the Drapers' Field Centre in Caernarvonshire to attend courses at the beginning of August last year, but the centre will not be formally opened until this month. Courses began at the other new centre, the Leonard Wills Field Centre at Nettlecombe Court, Taunton, at the end of February, although in the year under report building work was still in progress there.

Plans are also being made for the erection of the long awaited biological laboratory at the Dale Fort

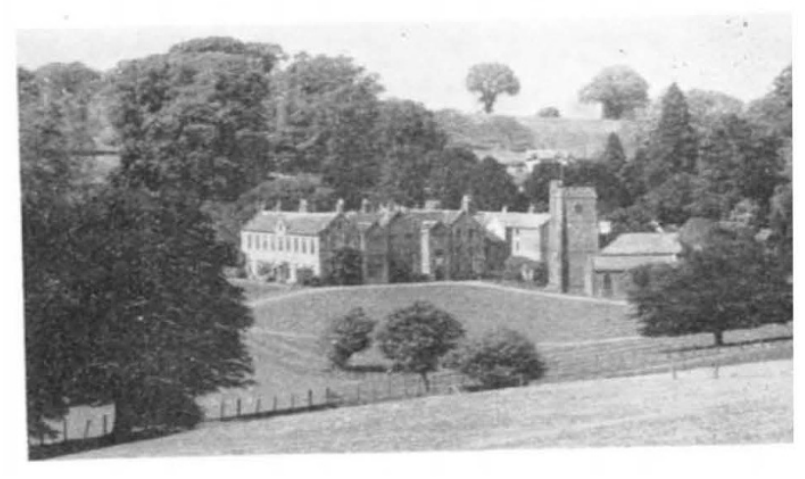

Nettlecombe Court and the thirteenth century church (copyright: $\mathrm{H}$. Hole).

Field Centre within the next twelve months, and the council is also negotiating for the freehold of the Preston Montford Estate as a prelude to long-term improvements at that centre.

The total number of student weeks at eight out of the nine centres taking students last year was again a record-12,538-but, without those at the Drapers' Field Centre, there was a slight fall in numbers attending the other centres. This reduction may have been a result of the cancellation of bookings, often at such a late stage that it was impossible to fill the vacant places.

The main function of the centres is the teaching of the various aspects of the environment, but some long- 
term research investigations are run, and the council is pleased to announce the employment of full-time research assistants at Preston Montford and Orielton.

The programmes of the different centres are full as usual. Courses offered this year range from 'Energy Relations in an Aquatic Ecosystem" at Slapton Ley from July 17-24, to "Some Aspects of Geomorphology" at Orielton from July 31-August 7. There are also arrangements for independent groups to work at the ientres.

\section{Congress and the "Hidden War"}

ONE of the powerful committees of the US Congress has taken up the International Biological Programme (IBP) in a big way. The Sub-committee on Science, Research and Development (led by House Representative Emilio P. Daddario) of the Committee on Science, and Astronautics may seem a strange forum for discus. sion of the IBP to those not learned in the infra-strueture of congressional committees, but, after all, the Earth is a planet like any other and more like than unlike in its capacity for sustaining biologically irreversible damage from the casual activities of man.

This is the theme of what is certain to be called the Daddario report ("The International Biological Program, its Meaning and Needs", published March 20, 1968). American participation in the IBP is seen as the major opportunity for breakout from a position of siege in "conflict between man and nature in a 'hidden war' with possibly disastrous consequences . . . which may be of a magnitude to dwarf any military war yet fought on Earth and of a scope to reduce any conventional type of combat to relative unimportance". The report spells out some of the potential disasters ahead if total environment (ecological) effects are disregarded, and makes recommendations on what can be done about it. In sum, this congressional group does not want to be part of a civilization which may go down in history "as an elegant technological society struck down by biological disintegration for lack of ecological understanding".

The seriousness of the situation and the importance of ecology in providing answers have so far escaped both the administration and general public. Representative Daddario points out that ". . . this is the most restrictive element which faces US participation in the IBP. ... Such concern as has been evidenced thus far by the Government-and that concern is relatively mildseems to have been fostered more by the conditioned response of Government to the prestige of the scientific community than to an understanding of the problem itself. This situation must change- or the IBP is not likely to get off the ground." This could wrell be echoed for the IBP as a whole.

Seven danger areas or practices are cited in the report: thermal pollution from the nuclear power programme, which is expected to supply as much electricity as serviced the whole of the United States 25 years ago and for which all the large freshwater flow sites have already been tagged for possible nuclear plant cooling; the rise in heat production through urbanization and population increase; radical changes in the atmospheric balance through similar causes plus jet travel; upset of the oxygen/carbon dioxide cycle through defoliation practices (likn those employed in Vietnam) and general reduction in global plant cover; the ruining of freshwater reserves by waste pollution-it is estimated that 500 years would be required to restore Lake Erie to the condition of only 25 years ago if all human polluting activity were halted immediately; loss of useful wildlife species"the prospect... of man living alone on his planet except for domesticated food animals and pets seems rather a dreary one"; the uncertainties of "human. quality control" opened up by genetic advances. "New data on a total environmental system of the type proposed by the IBP are apparently the only way out of the present dilemma which pits alarm versus indifference", the report comments.

The sub-committee criticizes both the organization and funding of the IBP in the United States. It recommends an adequate full-time staff and tighter managerial control and urges that the present ad hoc funding methods be dropped. Estimates of the cost of the US IBP programme (see Nature, 216, 842; 1967) have ranged from $\$ 50$ million to $\$ 200$ million. The sub-committee does not consider that the programme is sufficiently advanced to justify the $\$ 11$ million proposed for the first operational year (1969 in this case), but recommends the Federal Government to provide not less than $\$ 3$ million and not more than $\$ 5$ million for this period. Current rethinking may have the effect of consolidating the major US IBP projects into a single programme consistent with the theme of ecosystem analysis, with a consequent fall in "new money" demands to as little as $\$ 30$ million. "To accomplish a great deal with $\$ 30$ million may in the end not aceomplish enough."

\section{Unrest among French Scientists \\ from our Paris Correspondent}

Some 250 French scientists, together with representatives of several political parties, virtuously gave up the first Sunday of spring in order to hold in Paris a National Research Symposia. Even if the problems discussed were not defined particularly clearly and the solutions envisaged were in many cases vague or unrealistic, this event is in itself extremely significant. In effect, it marks an important stage in a development which seems to have been slower to take place in France than elsewhere. This is the consciousness of research workers that they belong to a single community which ought, in the face of public and government opinion, to define its objectives.

The speeches made were somewhat disparate, but there was a measure of agreement. Professors Kourilsky, Hamburger and Mathé, for example, deplored the way in which medical research in faculties of medicine and university teaching hospitals is run by the teachers and clinical workers, who enjoy a higher status than the rest. They traced a comparison (which was flattering for Great Britain) between conditions on either side of the Channel. For the rest, two preoccupations seemed to dominate most of the speechesthe need for a more coherent organization and for a more efficient deployment of research facilities. On both these themes there was a wide range of opinions, from highly technical discussions to political debates.

But the political contributions were generally dominant, and not all were on a happy note. Some of the outbursts from university factions wavered between a 